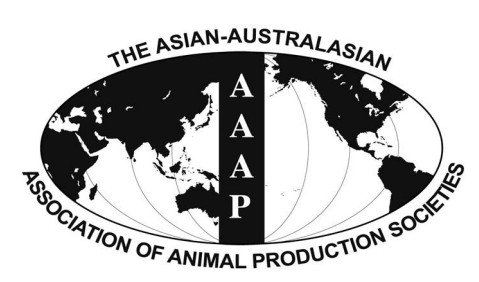

Open Access

Asian Australas. J. Anim. Sci.

Vol. 29, No. 2 : 204-210 February 2016

http://dx.doi.org/10.5713/ajas.15.0094

www.ajas.info

pISSN 1011-2367 elSSN 1976-5517

\title{
Effects of Cellulase Supplementation on Nutrient Digestibility, Energy Utilization and Methane Emission by Boer Crossbred Goats
}

\author{
Lizhi Wang and Bai Xue* \\ Institute of Animal Nutrition, Sichuan Agricultural University, Yaan 625014, Sichuan, China
}

\begin{abstract}
This study examined the effect of supplementing exogenous cellulase on nutrient and energy utilization. Twelve desexed Boer crossbred goats were used in a replicated $3 \times 3$ Latin square design with 23-d periods. Dietary treatments were basal diet (control, no cellulase), basal diet plus $2 \mathrm{~g}$ unitary cellulase/kg of total mixed ration dry matter (DM), and basal diet plus $2 \mathrm{~g}$ compound cellulase/kg of total mixed ration DM. Three stages of feeding trials were used corresponding to the three treatments, each comprised 23 $\mathrm{d}$, with the first $14 \mathrm{~d}$ as the preliminary period and the following $9 \mathrm{~d}$ as formal trial period for metabolism trial. Total collection of feces and urine were conducted from the 4th $\mathrm{d}$ of the formal trial, and gas exchange measures were determined in indirect respiratory chambers in the last $3 \mathrm{~d}$ of the formal trial. Results showed that cellulase addition had no effect $(\mathrm{p}>0.05)$ on nutrient digestibility. Dietary supplementation of cellulase did not affect ( $\mathrm{p}>0.05) \mathrm{N}$ intake and retention in goats. Gross energy (GE) intake, fecal energy and urinary energy excretion, heat production were not affected $(\mathrm{p}>0.05)$ by the cellulase supplementation. Total methane emission $(\mathrm{g} / \mathrm{d}), \mathrm{CH}_{4}$ emission as a proportion of live weight or feed intake (DM, organic matter [OM], digestible DM or digestible $\mathrm{OM}$ ), or $\mathrm{CH}_{4}$ energy output $\left(\mathrm{CH}_{4}-\mathrm{E}\right)$ as a proportion of energy intake (GE, digestible energy, or metabolizable energy), were similar ( $\left.\mathrm{p}>0.05\right)$ among treatments. There was a significant $(\mathrm{p}<0.001)$ relationship between $\mathrm{CH}_{4}$ and live weight $\left(\mathrm{y}=0.645 \mathrm{x}+0.2, \mathrm{R}^{2}=0.54\right), \mathrm{CH}_{4}$ and $\mathrm{DM}$ intake $\left(y=16.7 x+1.4, R^{2}=0.51\right), C_{4}$ and OM intake $\left(y=18.8 x+1.3, R^{2}=0.51\right)$ and $\mathrm{CH}_{4}-\mathrm{E}$ and $\mathrm{GE}$ intake. Results from this study revealed that dietary supplementation of cellulase may have no effect on nutrient digestibility, nitrogen retention, energy metabolism, and methane emission in goat. (Key Words: Cellulase, Digestibility, Energy, Goat, Nutrients, Methane)
\end{abstract}

\section{INTRODUCTION}

Cellulase is believed to be effective in improving nutrient digestibility of ruminants, especially rumen degradability of fiber. Ballard et al. (2003) reported that dietary addition of compound cellulase (CC) increased the apparent digestibility of dry matter (DM), organic matter (OM), and neutral detergent fiber (NDF) of dairy cows. Bilik and Łopuszańska-Rusek (2010) reported that the addition of exogenous cellulase may increase total volatile fatty acid (VFA) of rumen fluid of dairy cows without disturbing the VFA profile. Rumen VFA is the energy source for ruminants, and therefore it could be deduced that exogenous cellulase might affect energy metabolism of ruminants. There have been considerable research on the

\footnotetext{
* Corresponding Author: Bai Xue. Tel: +86-835-2885065, Fax: +86-835-2885065, E-mail: Xuebai2000@yahoo.com

Submitted Feb. 3, 2015; Revised Apr. 8, 2015; Accepted May 23, 2015
}

energy metabolism of different species of ruminants, but no research on the effect of exogenous cellulase supplementation on energy metabolism of ruminants has been reported. As the evidence for nutrient digestibility being elevated by exogenous cellulase accumulated (McAllister et al., 2000; Tang et al., 2013; Vijay Bhasker et al., 2013), this study hypothesized that energy utilization could also be affected by the dietary addition of exogenous cellulase. Therefore, the objective of this study was to determine the effects of exogenous cellulase on nutrient utilization by Boer crossbred goats.

\section{MATERIALS AND METHODS}

All animals in this study were cared for according to the standards set by the Chinese guidelines for animal welfare and the experimental protocol was approved by the Animal Care and Use Committee of the Chinese Academy of 
Sciences.

\section{Animals and diets}

Twelve castrated Boer crossbred goats (Boer $\times$ Jianchang Black), average body weight (BW) $20 \pm 1.51 \mathrm{~kg}$ and aged around 10 months, were used in a four replicate $3 \times 3$ Latin square design. These goats were purchased from farmers around Chengdu. The sexual maturity of this species is at 7 to 8 months of age, and the growing age until 12 months of age. They were housed individually in metabolism cages designed to separately collect feces and urine. Before the experiment, goats were dewormed for internal parasites with albendazole (Yakang Animal pharmacy, Weifang, Shandong, China) at $12 \mathrm{mg} / \mathrm{kg} \mathrm{BW}$. There were three experimental periods corresponding to three treatments. Each stage comprised 21-d periods, with the first $14 \mathrm{~d}$ as the adaptation period and the following $9 \mathrm{~d}$ as the measurement period including $6 \mathrm{~d}$ in crates and 3 in chambers.

From $\mathrm{d} 1$ to $\mathrm{d} 6$ of the formal trial, goats were kept in metabolism cages for total collection of feces and urine. On d 7 of the formal trial, the goats were transferred into respiratory chambers for adaptation; on $\mathrm{d} 8$ and $\mathrm{d} 9$, the goats were subject to gas exchange measurements in respiratory chambers for measuring oxygen consumption, carbon dioxide output, and methane output. Total feces and urine were collected daily both in chambers and in metabolism cages.

The experimental diet comprised of $30 \%$ concentrate, $35 \%$ alfalfa and $35 \%$ Chinese wildrye (Table 1), and was formulated to provide adequate digestible energy (DE) and

Table 1. The ingredient and chemical composition of the diet (DM basis)

\begin{tabular}{lc}
\hline Items & Content (\%) \\
\hline Ingredients & \\
Alfalfa & 35 \\
Wildrye & 35 \\
Corn & 11 \\
Soybean meal & 5 \\
Wheat bran & 13 \\
Premix ${ }^{1}$ & 0.5 \\
NaCl & 0.5 \\
Total & 100 \\
Nutrient levels ${ }^{2}$ & \\
Gross energy (MJ/kg) & 17.0 \\
Dry matter (\%) & 88.8 \\
Crude protein (\%) & 11.9 \\
Lipid & 2.0 \\
Ash & 10.7 \\
Neutral detergent fiber (\%) & 38.9 \\
Acid detergent fiber (\%) & 28.9 \\
\hline${ }^{1}$ Premix provides: Fe 30 ppm; Cu 10 ppm; Zn 50 ppm; Mn 60 ppm; Vit. A \\
2,937 IU; Vit. D 343 IU; Vit. E 30 IU.
\end{tabular}

crude protein (CP) for a $20-\mathrm{kg}$ goat gaining $100 \mathrm{~g} / \mathrm{d}$ of body weight according to NRC (1981). Dietary treatments were basal diet (control, no cellulase), basal diet plus $2 \mathrm{~g}$ unitary cellulase (UC)/kg of ration DM, and basal diet plus $2 \mathrm{~g}$ $\mathrm{CC} / \mathrm{kg}$ of ration DM. The enzymes (UC and CC) used in this study were commercial preparations of fungal extracts (Youter Biotechology Shanghai Co., Ltd., Shanghai, China). The UC additive contained 10,000 IU/g of cellulase (endoglucanase, EC 3.2.1.4) activity, while CC additive contained 7,000 IU/g of cellulase (endoglucanase, EC 3.2.1.4) and $5,000 \mathrm{IU} / \mathrm{g}$ of xylanase $(1,4-\beta$-xylanase, EC 3.2.1.8) activity. Cellulase activity was determined at $39^{\circ} \mathrm{C}$ and $\mathrm{pH} 6.0$ using carboxymethyl cellulose (catalog no. C5678; Sigma Chemical Co., St. Louis, MO, USA) as substrates and xylanase activity was determined at $50^{\circ} \mathrm{C}$ and $\mathrm{pH} 5.5$ using birchwood xylan (catalog no. X-0502; Sigma Chemical Co., USA) as substrates. The enzyme additive (i.e., $2 \mathrm{~g}$ of the enzyme additive per $\mathrm{kg}$ of ration $\mathrm{DM}$ for UC and CC treatment) was first diluted in $40 \mathrm{~mL}$ of water, and the dilution was added to the concentrate at the time of mixing, usually within $1 \mathrm{~h}$ before feeding. An equal amount of water $(40 \mathrm{~mL} / \mathrm{kg}$ of concentrate DM) was added to the control diet. Experimental diets were fed to goats for ad libitum intake twice daily with equal amounts at 1,000 and $1,600 \mathrm{~h}$, and fresh water was available freely at all times.

\section{Measurements}

Live weight was recorded for 3 consecutive days in the morning before feeding at the beginning and end of each period. Feed intake for individual goats was recorded daily during the 9-d formal trial in each period. Experimental diets, dietary ingredients, and refusals for individual goats were sampled at the beginning and end of formal trial of each period and composited by period. Periodical refusals, experimental diets, and ingredients were stored at $-20^{\circ} \mathrm{C}$ until analyzed. Feces were collected daily in wire-screen baskets placed under the floor of metabolism crates, and urine was collected through a funnel into plastic buckets. Urine and feces were weighed daily. Urine was acidified with $10 \% \mathrm{HCl}$ ( $\mathrm{vol} / \mathrm{vol}, 5 \%$ of urine), and feces were preserved with $10 \%$ formaldehyde (vol/vol, 3\% of feces) and thoroughly mixed. Urine and feces were sub-sampled daily after acidification and preservation, and stored frozen at $-20^{\circ} \mathrm{C}$ for later analysis.

Feed offered, refusals, and fecal samples were dried in a forced-air oven at $65^{\circ} \mathrm{C}$ for $48 \mathrm{~h}$, then ground to pass through a 1-mm screen, and were analyzed for DM, gross energy (GE) (AOAC, 1990), and NDF (filter bag technique; China Agricultural University). Urine samples were assayed for $\mathrm{N}$ and GE concentrations.

For calorimetry measures, goats were moved into indirect open-circuit calorimetry chambers. The 
concentration of $\mathrm{O}_{2}, \mathrm{CO}_{2}$ and $\mathrm{CH}_{4}$ were analyzed using gas chromatography. Before the gas exchange measurements, validity and accuracy of expired $\mathrm{CO}_{2}$ and inspired $\mathrm{O}_{2}$ flows were checked with ethane combustion with the same flow rates as used during measurements. Before each test, analyzers were calibrated with reference gases: $99.99 \% \mathrm{O}_{2}$, 99.99\% $\mathrm{CO}_{2}$, and $99.99 \% \mathrm{CH}_{4}$. Temperature and humidity in the chambers was maintained at $23^{\circ} \mathrm{C}$ and $50 \%$ to $55 \%$, respectively.

\section{Calculations}

Metabolizable energy intake (MEI) was calculated by the difference between GE intake (GEI) and energy losses in feces (FE), urine (UE), and $\mathrm{CH}_{4}\left(\mathrm{CH}_{4} \mathrm{E}\right)$

$$
\mathrm{MEI}=\mathrm{GEI}-\mathrm{FE}-\mathrm{UE}-\mathrm{CH}_{4} \mathrm{E}
$$

Heat production (HP) was estimated based on the Brouwer (1965) equation: (g)

$$
\mathrm{HP}(\mathrm{Kj})=16.1735 \times \mathrm{O}_{2}(\mathrm{~L})+5.0208 \times \mathrm{CO}_{2}(\mathrm{~L})-5.9873 \times \mathrm{UN}
$$

$\mathrm{CH}_{4}$ contains $39.5388 \mathrm{~kJ} / \mathrm{L}$ energy as reported by Brouwer (1965). Retained energy (RE) was determined as the difference between MEI and HP.

\section{Statistical analyses}

Data were analyzed using the MIXED procedure (SAS Institute Inc., Cary, NC, USA; Littell et al., 1996). Goat was the experimental unit for all variables. The full general linear model (GLM) model included the fixed effects of square, period nested within square, treatment (control, UC and CC enzyme), sampling time (day), and the interaction of treatment and sampling time. For all data, if the interaction of treatment by sampling time was not significant ( $p>0.05)$, the fixed effect of sampling time and its related interaction were removed from the full GLM model. Sampling time was a repeated effect in the model. Goat nested within square was used in the random statement. Differences were declared significant at $p \leq 0.05$, and a tendency to significance was declared at $0.05<\mathrm{p} \leq 0.10$. Means were separated using Duncan's multiple contrasts.

\section{RESULTS AND DISCUSSION}

\section{Nutrient digestibility}

There was no significant difference $(\mathrm{p}>0.05)$ in live weight, live weight gain and DM intake among treatments. Digestibility of DM, OM, CP, crude fat, NDF and acid detergent fiber (ADF) were not affected $(\mathrm{p}>0.05)$ by cellulase treatments (Table 2).

There are controversial reports on total tract digestibility of DM and OM or both, following cellulase treatments. Some researchers observed a positive effect of treatment with exogenous cellulase on DM or organic digestibility (Lewis et al., 1996; Rode et al., 1999) while some other studies observed no effect (Lewis et al., 1999; McAllister et al., 2000; Yang et al., 2000). However, present results found that cellulase addition had no effect on DM and OM digestibility. Some researchers found that NDF and ADF digestibility increased following cellulase treatments (Lewis et al., 1999; McAllister et al., 2000), but these results were not observed in this study. The contradictory reports on the effect of cellulase on nutrient digestibility may be due to the digestion characteristics of the rations. Yang et al. (2000) noted that exogenous cellulase improved digestibility of low quality rations, but no effect was evident with high quality rations. This viewpoint still needs confirmation, because O'Connor et al. (2007) found that nutrient

Table 2. The effects of enzyme treatments on apparent nutrient digestibility and $\mathrm{N}$ metabolism in growing goats

\begin{tabular}{lccccc}
\hline Item & Control & Cellulase & Cellulase/xylanase & SE & p-value \\
\hline Live weight (kg) & 22.8 & 22.7 & 22.9 & 0.45 & 0.967 \\
DM intake (kg) & 0.86 & 0.84 & 0.87 & 0.017 & 0.538 \\
DM digestibility & 62.30 & 65.94 & 63.61 & 0.75 & 0.129 \\
OM digestibility & 63.92 & 67.28 & 65.08 & 0.71 & 0.151 \\
EE digestibility & 51.26 & 52.19 & 50.70 & 2.01 & 0.957 \\
NDF digestibility & 49.54 & 53.36 & 50.55 & 0.89 & 0.187 \\
ADF digestibility & 47.15 & 56.86 & 54.68 & 2.02 & 0.157 \\
N intake (g/d) & 16.37 & 16.01 & 16.51 & 0.012 & 0.698 \\
Fecal N (g/d) & 6.05 & 5.54 & 6.10 & 0.007 & 0.097 \\
N digestibility (\%) & 62.99 & 65.34 & 63.13 & 0.46 & 0.063 \\
Urine N (g/d) & 4.12 & 5.29 & 4.66 & 0.217 & 0.075 \\
Urine N/N intake (\%) & 25.67 & 33.14 & 26.38 & 0.015 & 0.135 \\
Digestible N (g/d) & 10.32 & 10.48 & 10.39 & 0.011 & 0.647 \\
NR (g/d) & 5.36 & 5.94 & 6.28 & 0.163 & 0.369 \\
NR/N intake (\%) & 32.74 & 37.10 & 38.04 & 1.463 & 0.371 \\
NR/digestible N (\%) & 53.46 & 56.82 & 57.78 & 2.319 & 0.205 \\
\hline SE, sta
\end{tabular}

SE, standard error; DM, dry matter; OM, organic matter; EE, ether extract; NDF, neutral detergent fiber; ADF, acid detergent fiber; NR, N retention. 
Table 3. Effects of dietary addition of exogenous cellulase on enteric methane emission in growing goats

\begin{tabular}{lccccc}
\hline Items & Control & Cellulase & Cellulase/xylanase & SE & p-value \\
\hline $\mathrm{CH}_{4}$ (L/d) & 21.84 & 21.84 & 21.70 & 0.47 & 0.976 \\
$\mathrm{CH}_{4} / \mathrm{live}$ weight (L/kg) & 0.96 & 0.96 & 0.95 & 0.022 & 0.746 \\
$\mathrm{CH}_{4} / \mathrm{DM}$ intake (L/kg) & 25.40 & 26.00 & 24.94 & 0.39 & 0.414 \\
$\mathrm{CH}_{4} / \mathrm{OM}$ intake (L/kg) & 28.56 & 29.26 & 28.14 & 0.44 & 0.414 \\
$\mathrm{CH}_{4} / \mathrm{DDMI}(\mathrm{L} / \mathrm{kg})$ & 40.76 & 39.45 & 39.22 & 0.72 & 0.563 \\
$\mathrm{CH}_{4} / \mathrm{DOMI}(\mathrm{L} / \mathrm{kg})$ & 44.70 & 43.48 & 43.23 & 0.77 & 0.634 \\
$\mathrm{CH}_{4}$-E/GE (\%) & 6.0 & 6.1 & 5.9 & 0.13 & 0.435 \\
$\mathrm{CH}_{4}$-E/DE (\%) & 9.3 & 9.0 & 9.0 & 0.23 & 0.589 \\
$\mathrm{CH}_{4}$-E/ME (\%) & 10.6 & 10.3 & 10.4 & 0.29 & 0.725 \\
\hline
\end{tabular}

SE, standard error; DM, dry matter; OM, organic matter; DDMI, digestible dry matter intake; DOMI, digestible organic matter intake; GE, gross energy; ME, metabolizable energy.

digestibility even decreased when cellulase was added to high quality forage diets of horses. Therefore, the effect and mechanisms of exogenous cellulase on nutrient digestion are still incompletely understood. Yang et al. (1999) speculated that improved digestibility caused by exogenous cellulase was due to improved microbial colonization. Wang et al. (2001) and Morgavi et al. (2004) found associative effects between exogenous cellulase and cellulase from rumen micro-organisms. Therefore, exogenous cellulase may improve nutrient digestibility by improving colonization and by stimulating the endogenous enzyme activity within the rumen. But such improved colonization and stimulated endogenous enzyme activity may be related to forage type or ration type.

\section{Nitrogen balance}

There was no difference $(\mathrm{p}>0.05)$ on $\mathrm{N}$ intake, fecal $\mathrm{N}$ and urinary $\mathrm{N}$ among the treatments. $\mathrm{N}$ retention (NR) and $\mathrm{N}$ retention rate $(\mathrm{NR} / \mathrm{NI})$ were not affected $(\mathrm{p}>0.05)$ by the addition of cellulase (Table 2).

Awawdeh and Obeidat (2011) found no effect on NR of lamb after the addition of cellulase at $20 \mathrm{~g} / \mathrm{d}$. Although it has been documented that ruminal microbial protein synthesis could be stimulated by the addition of cellulase (Hristov et al., 1998; Rode et al., 1999), however, this result may not be sufficient to explain the subsequent effect on NR. Gado et al. (2009) added cellulase at the rate of $40 \mathrm{~g} / \mathrm{d}$ in cow diets ( $30 \%$ concentrate), and found no effect on NR and utilization, also microbial protein synthesis was increased. In the present study, the supplementation of cellulase had no effect on NR in goats which is in agreement with the report of Gado et al. (2009) with cows, but in conflict with McAllister et al. (2000) in lambs.

\section{Effect of exogenous cellulase on energy metabolism}

No significant $(\mathrm{p}>0.05)$ difference was evident on GE intake, fecal energy and urinary energy excretion, $\mathrm{CH}_{4}$ energy, heat production and RE among treatments (Table 4). The addition of UC and CC could significantly increase the DE/GEI and ME/GEI, but did not affect HP/GEI (Table 4).

Few studies concerning the effect of cellulase on energy utilization of livestock have been reported. O'Connor et al. (2007) reported that cellulase supplementation did not improve GE digestibility of horses. In fact, horses consuming the control ration digested a greater $(p<0.05) \mathrm{GE}$ than those consuming the ration with cellulase

Table 4. Effects of dietary addition of exogenous cellulase on energy metabolism of growing goats

\begin{tabular}{|c|c|c|c|c|c|}
\hline Item & Control & Cellulase & Cellulase/xylanase & $\mathrm{SE}$ & p-value \\
\hline$\overline{\text { GE intake }(\mathrm{MJ} / \mathrm{d})}$ & 14.57 & 14.23 & 14.69 & 0.270 & 0.473 \\
\hline Fecal energy $(\mathrm{MJ} / \mathrm{d})$ & 5.21 & 4.58 & 5.08 & 0.194 & 0.072 \\
\hline DE intake (MJ/D) & 9.37 & 9.65 & 9.61 & 0.252 & 0.694 \\
\hline $\mathrm{UE}(\mathrm{MJ} / \mathrm{d})$ & 0.28 & 0.32 & 0.32 & 0.023 & 0.420 \\
\hline $\mathrm{CH}_{4}(\mathrm{MJ} / \mathrm{d})$ & 0.87 & 0.87 & 0.86 & 0.026 & 0.976 \\
\hline ME intake $(\mathrm{MJ} / \mathrm{d})$ & 8.24 & 8.46 & 8.42 & 0.223 & 0.746 \\
\hline $\mathrm{HP}(\mathrm{MJ} / \mathrm{d})$ & 4.21 & 4.28 & 4.25 & 0.065 & 0.889 \\
\hline $\mathrm{CH}_{4} / \mathrm{GE}$ & 0.059 & 0.060 & 0.058 & 0.007 & 0.735 \\
\hline $\mathrm{CH}_{4} / \mathrm{DE}$ & 0.092 & 0.089 & 0.089 & 0.003 & 0.854 \\
\hline $\mathrm{ME}(\mathrm{MJ} / \mathrm{d})$ & 8.30 & 8.54 & 8.49 & 0.183 & 0.864 \\
\hline $\mathrm{RE}(\mathrm{MJ} / \mathrm{d})$ & 4.09 & 4.26 & 4.24 & 0.198 & 0.942 \\
\hline DE/GE (\%) & 64.25 & 67.88 & 65.54 & 0.007 & 0.127 \\
\hline ME/GE (\%) & 56.57 & 59.61 & 57.53 & 0.007 & 0.202 \\
\hline HP/ME (\%) & 29.03 & 30.09 & 29.02 & 0.006 & 0.699 \\
\hline
\end{tabular}

SE, standard error; GE, gross energy; DE, digestible energy; UE, urine; ME, metabolizable energy; HP, heat production; RE, retained energy. 
Table 5. The relationships between methane emission and live weight, feed intake or energy intake in growing goats

\begin{tabular}{llcc}
\hline Item & \multicolumn{1}{c}{ Equations $^{\mathrm{a}}$} & $\mathrm{SE}$ & $\mathrm{R}^{2}$ \\
\hline $\mathrm{CH}_{4}(\mathrm{~g} / \mathrm{d})=$ & $0.674_{(0.108)}$ Live weight $(\mathrm{kg})+0.22_{(2.47)}$ & 1.15 & 0.54 \\
& $16.8_{(2.82)} \mathrm{DM}$ intake $(\mathrm{kg} / \mathrm{d})+1.3_{(2.41)}$ & 1.18 & 0.51 \\
& $18.8_{(3.16)} \mathrm{OM}$ intake $(\mathrm{kg} / \mathrm{d})+1.3_{(2.41)}$ & 1.18 & 0.51 \\
& $18.5_{(3.36)} \mathrm{DDM}$ intake $(\mathrm{kg} / \mathrm{d})+5.5_{(1.84)}$ & 1.22 & 0.47 \\
& $21.0_{(3.75)} \mathrm{DOM}$ intake $(\mathrm{kg} / \mathrm{d})+5.2_{(1.88)}$ & 1.21 & 0.48 \\
$\mathrm{CH}_{4}-\mathrm{E}(\mathrm{MJ} / \mathrm{d})=$ & $0.055_{(0.0092)} \mathrm{GE}$ intake $(\mathrm{MJ} / \mathrm{d})+0.073_{(0.1340)}$ & 0.0655 & 0.51 \\
& $0.058_{(0.0109)}$ DE intake $(\mathrm{MJ} / \mathrm{d})+0.35_{(0.1050)}$ & 0.0691 & 0.45 \\
& $0.057_{(0.0127)} \mathrm{ME}$ intake $(\mathrm{MJ} / \mathrm{d})+0.393_{(0.1070)}$ & 0.0742 & 0.37 \\
\hline
\end{tabular}

SE, standard error; DM, dry matter; OM, organic matter; DDM, digestible DM; DOM, digestible OM; GE, gross energy; DE, digestible energy; ME, metabolizable energy.

${ }^{a}$ The data in brackets are SE values.

supplementation. Results from the present study showed that GE intake, fecal energy and urinary energy excretion, methane energy and heat production were not affected by the addition of cellulase.

\section{Effect on methane emission}

There were no significant differences among dietary treatments on total $\mathrm{CH}_{4}$ emissions $(\mathrm{g} / \mathrm{d}), \mathrm{CH}_{4}$ emission as a proportion of live weight or feed intake (DM, OM, digestible $\mathrm{DM}$ or digestible $\mathrm{OM}$ ), or $\mathrm{CH}_{4}$ energy output $\left(\mathrm{CH}_{4}-\mathrm{E}\right)$ as a proportion of energy intake (GE, DE, or ME) (Table 3). There was a significant $(\mathrm{p}<0.001)$ relationship between $\mathrm{CH}_{4}$ and live weight $\left(\mathrm{y}=0.645 \mathrm{x}+0.2, \mathrm{R}^{2}=0.54\right)$, $\mathrm{CH}_{4}$ and DM intake $\left(\mathrm{y}=16.7 \mathrm{x}+1.4, \mathrm{R}^{2}=0.51\right), \mathrm{CH}_{4}$ and $\mathrm{OM}$ intake $\left(\mathrm{y}=18.8 \mathrm{x}+1.3, \mathrm{R}^{2}=0.51\right)$ and $\mathrm{CH}_{4}-\mathrm{E}$ and $\mathrm{GE}$ intake (Table 5 and Figure 1).

Methane emission from ruminants is receiving an increased level of public attention. Different varieties of additives were tested for the mitigation of methane emission. Except for plant extracts, ionophores such as monensin or lasalocid (Guan et al., 2006), supplemental fat (Jordan et al., 2006), halogenated analogues such as bromochloromethane (Abecia et al., 2012) were studied for the possible usage in the mitigation of methane emission from ruminants. But till now, very few studies concerning the effect of cellulase on methane emission have been reported (Tang et al., 2013). Eun and Beauchemin (2007) reported that properly formulated cellulase can lower the acetate-to-propionate ratio, which is thought to be the primary mechanism of methane abatement. Apparently this hypothesis was not supported by our study. Chung et al. (2012) even found negative results, e.g. enteric methane of dairy cow increased linearly with an increasing level of cellulase supplement.
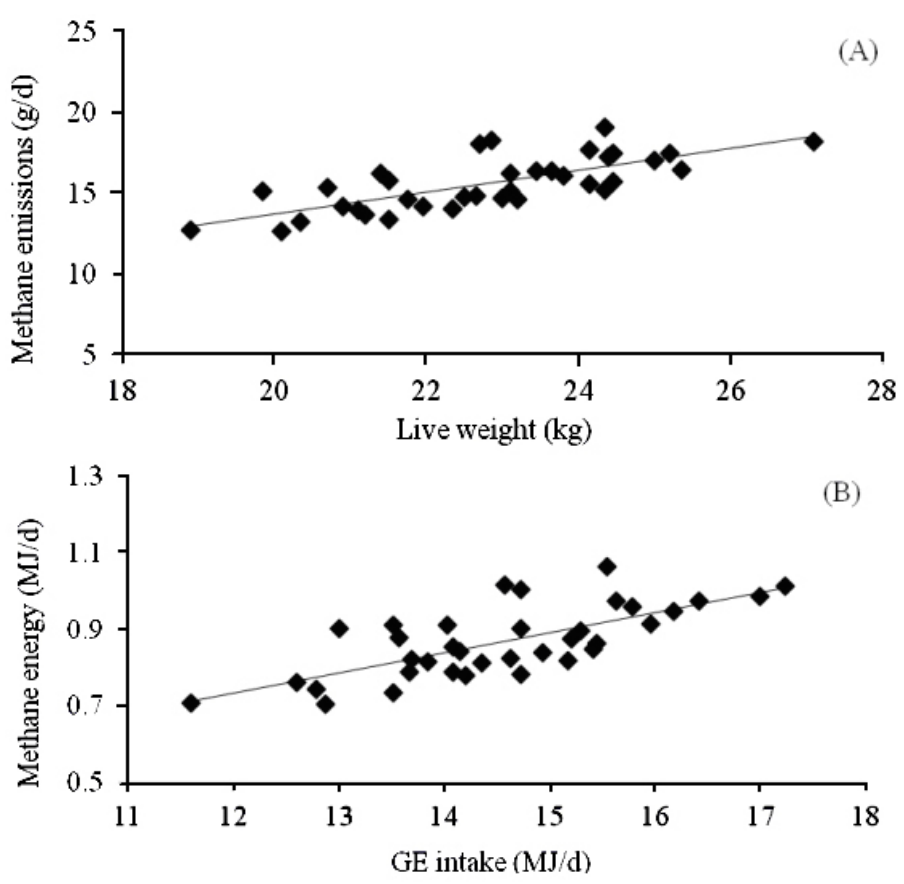

Figure 1. The linear relationships between methane emission and live weight (A), and between methane energy put and gross energy (GE) intake (B) in growing goats. 
The $\mathrm{CH}_{4}$-E/GE intake ranged from 0.059 to 0.061 , which is within recommendations of IPCC (2006) for lambs $(0.045)$ and mature sheep $(0.065)$ for development of Tier 2 emission inventories. There is no recommendation of $\mathrm{CH}_{4}-$ E/GE intake for goats in IPCC (2006).

\section{CONCLUSION}

On the basis of above results, it may be concluded that cellulase addition had no effect on dry matter intake, nutrients digestibility and $\mathrm{N}$ utilization in goats. GE intake, fecal energy and urinary energy excretion, methane emission, heat production were also not affected by the cellulase supplementation.

\section{IMPLICATIONS}

The results from this study implicated that exogenous cellulase has no effect on nutrients digestion and $\mathrm{N}$ utilization in goats fed on high roughage diet irrespective of sources used. Supplementation of cellulase may not be an effective additive for methane mitigation.

\section{CONFLICT OF INTEREST}

We certify that there is no conflict of interest with any financial organization regarding the material discussed in the manuscript.

\section{REFERENCES}

Abecia, L., P. G. Toral, A. I. Martín-García, G. Martínez, N. W. Tomkins, E. Molina-Alcaide, C. J. Newbold, and D. R. YanezRuiz. 2012. Effect of bromochloromethane on methane emission, rumen fermentation pattern, milk yield, and fatty acid profile in lactating dairy goats. J. Dairy Sci. 95:2027-2036.

Awawdeh, M. S. and B. S. Obeidat. 2011. Effect of supplemental exogenous enzymes on performance of finishing Awassi lambs fed olive cake-containing diets. Livest. Sci. 138:20-24.

Ballard C. S., M. P. Carter, K. W. C. Tach, C. J. Sniffen, T. Sato, K. Uchida, A. Teo, U. D. Nhan, and T. H. Meng. 2003. Feeding fibrolytic enzymes to enhance DM and nutrient digestion and milk production by dairy cows. J. Dairy Sci. 86(Suppl. 1):150 (Abstr.).

Beauchemin, K. A., M. Kreuzer, F. O’Mara, and T. A. McAllister. 2008. Nutritional management for enteric methane abatement: A review. Aust. J. Exp. Agric. 48:21-27.

Bhasker, T. V., D. Nagalakshmi, and D. S. Rao. 2013. Development of appropriate fibrolytic enzyme combination for maize stover and its effect on rumen fermentation in sheep. Asian Australas. J. Anim. Sci. 26:945-951.

Bilik, K. and M. Łopuszańska-Rusek. 2010. Effect of adding fibrolytic enzymes to dairy cow rations on digestive activity in the rumen. Ann. Anim. Sci. 10:127-137.

Brouwer E. 1965. Report on subcommittee on constants and factors. Proc. 3rd EAAP Symp on Energy Metabolism. pp 441-
443. Troon Publ., 11, Academic Press, London, UK.

Chung, Y. H., M. Zhou, L. Holtshausen, T. W. Alexander, T. A. McAllister, L. L. Guan, M. Oba, and K. A. Beauchemin. 2012. A fibrolytic enzyme additive for lactating Holstein cow diets: ruminal fermentation, rumen microbial populations, and enteric methane emissions. J. Dairy Sci. 95:1419-1427.

Eun, J. S. and K. A. Beauchemin. 2007. Assessment of the efficacy of varying experimental exogenous fibrolytic enzymes using in vitro fermentation characteristics. Anim. Feed Sci. Technol. 132:298-315

Gado, H. M., A. Z. M. Salem, P. H. Robinson, and M. Hassan. 2009. Influence of exogenous enzymes on nutrient digestibility, extent of ruminal fermentation as well as milk production and composition in dairy cows. Anim. Feed Sci. Technol. 154:3646.

Guan, H., K. M. Wittenberg, K. H. Ominski, and D. O. Krause. 2006. Efficacy of ionophores in cattle diets for mitigation of enteric methane. J. Anim. Sci. 84:1896-1906.

Hristov, A. N., T. A. McAllister, and K. J. Cheng. 1998. Effect of dietary or abomasal supplementation of exogenous polysaccharide-degrading enzymes on rumen fermentation and nutrient digestibility. J. Anim. Sci. 76:3146-3156.

IPCC, "2006 IPCC Guidelines for National Greenhouse Gas Inventories" http://www.ipcc-nggip.iges.or.jp/public/2006gl/ Accessed on October 10, 2014.

Jordan, E., D. K. Lovett, F. J. Monahan, J. Callan, B. Flynn, and F. P. O'Mara. 2006. Effect of refined coconut oil or copra meal on methane output and on intake and performance of beef heifers. J. Anim. Sci. 84:162-170.

Lewis, G. E., W. K. Sanchez, C. W. Hunt, M. A. Guy, G. T. Pritchard, B. I. Swanson, and R. J. Treacher. 1999. Effect of direct-fed fibrolytic enzymes on the lactational performance of dairy cows. J. Dairy Sci. 82:611-617.

Lewis, G. E., C. W. Hunt, W. K. Sanchez, R. Treacher, G. Pritchard, and P. Feng. 1996. Effect of direct-fed fibrolytic enzymes on the digestive characteristics of a forage-based diet fed to beef steers. J. Anim. Sci. 74: 3020-3028.

Littell R. C., G. A. Milliken, W. W. Stroup, and R. D. Wolfinger. 1996. SAS System for Mixed Models. SAS Institute, Inc. Cary, NC, USA.

McAllister, T. A., K. Stanford, H. D. Bae, R. J. Treacher, A. N. Hristov, J. Baah, J. A. Shelford, and K. J. Cheng. 2000. Effect of a surfactant and exogenous enzymes on digestibility of feed and on growth performance and carcass traits of lambs. Can. J. Anim. Sci. 80:35-44.

Morgavi, D. P., K. A. Beauchemin, V. L. Nsereko, L. M. Rode, T. A. McAllister, and Y. Wang. 2004. Trichoderma enzymes promote Fibrobacter succinogenes S85 adhesion to, and degradation of, complex substrates but not pure cellulose. J. Sci. Food Agric. 84:1083-1090.

O'Connor-Robison, C. I., B. D. Nielsen, and R. Morris. 2007. Cellulase supplementation does not improve the digestibility of a high-forage diet in horses. J. Equine Vet. Sci. 27:535-538.

Rode, L. M., W. Z. Yang, and K. A. Beauchemin. 1999. Fibrolytic enzyme supplements for dairy cows in early lactation. J. Dairy Sci. 82:2121-2126.

Tang, S. X., Y. Zou, M. Wang, A. Z. M. Salem, N. E. Odongo, C. S. Zhou, X. F. Han, Z. L. Tan, M. Zhang, and Y. F. Fu. 2013. Effects of exogenous cellulase source on in vitro fermentation 
characteristics and methane production of crop straws and Yang, W. Z., K. A. Beauchemin, and L. M. Rode. 1999. Effects of grasses. Anim. Nutr. Feed Technol. 13:489-505.

Wang, Y., T. A. McAllister, L. M. Rode, K. A. Beauchemin, D. P. an enzyme feed additive on extent of digestion and milk production of lactating dairy cows. J. Dairy Sci. 82:391-403. Morgavi, V. L. Nsereko, A. D. Iwaasa, and W. Yang. 2001.
Effects of an exogenous enzyme preparation on microbial protein synthesis, enzyme activity and attachment to feed in the Rumen Simulation Technique (Rusitec). Br. J. Nutr. Yang, W. Z., K. A. Beauchemin, and L. M. Rode. 2000. A comparison of methods of adding fibrolytic enzymes to lactating cow diets. J. Dairy Sci. 83:2512-2520. 85:325-332. 